\title{
WILLS AND INVENTORIES
}

\author{
FROM THE
}

REGISTERS OF THE

\section{COMMISSARY OF BURY ST. EDMUND'S}

AND THE

\section{ARCHDEACON OF SUDBURY.}

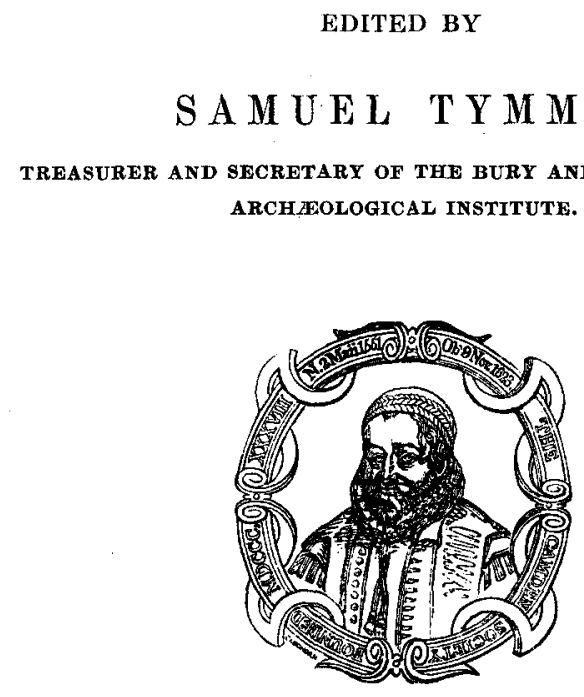

PRINTED FOR THE CAMDEN SOCIETY.

M.DCCC.L. 
LONDON :

J. B. NICHOLS AND SON, PRINTERS, PARLIAMENT STREET.

[No. XLIX.] 


\title{
COUNCIL
}

\author{
or \\ THE CAMDEN SOCIETY \\ FOR THE YEAH 1850. \\ President,
}

THE RIGHT HON. LORD BRAYBROOKE, F.S.A.

JOHN YONGE AKERMAN, ESQ. Sec. SA.

THOMAS AMYOT, ESQ. F.R.S., F.S.A. Director.

WILLTAM HENRY BLAAUW, ESQ. M.A. F.S.A.

JOHN BRUCE, ESQ. Treas. S.A.

JOHN PAYNE COLLIER, ESQ. V.P.S.A. Treasurer.

C. PURTON COOPER, ESQ. Q.C., D.C.L., F.R.S., F.S.A.

WILLIAM DURRANT COOPER, ESQ. F.S.A.

BOLTON CORNEY, ESQ. M.R.S.L.

SIR HENRY ELLIS, K.H., F.R.S., Sec. S.A.

THE REV. JOSEPH HUNTER, F.S.A.

PETER LEVESQUE, ESQ. F.S:A.

SIR FREDERIC MADDEN, K.H.

FREDERIC OUVRY, ESQ. F.S.A.

WILLIAM J. THOMS, ESQ. F.S.A., Secretary.

THOMAS WRIGH'T, ESQ. M.A. F.S.A. 
The Councin of the Campen Societry desire it to be understood that they are not answerable for any opinions or observations that may appear in the Society's publications; the Editors of the several works being alone responsible for the same. 
THE MOST HONOURABLE

FREDERICK WILLTAM MARQUESS OF BRISTOL, CHIEF STEWARD OF THE LIBERTY OF ST. EDMUND,

\&c. \&c. \&c.

THIS VOLUME

IS,

WITH HIS LORDSHIP'S KIND PERMISSION,

MOST RESPECTFULLY INSCRIBED. 